\title{
Curcumin inhibits telomerase activity in human cancer cell lines
}

\author{
SHU-XIANG CUI ${ }^{1}$, XIAN-JUN QU $^{2}$, YAN-YING XIE ${ }^{1}$, LING ZHOU $^{1}$, \\ MUNEHIRO NAKATA ${ }^{2,4}$, MASATOSHI MAKUUCHI ${ }^{3}$ and WEI TANG ${ }^{1,3}$
}

\begin{abstract}
${ }^{1}$ Department of Pharmacology, Institute of Materia Medica, Shandong Academy of Medical Sciences; ${ }^{2}$ Department of Pharmacology, College of Pharmacy, Shandong University, Jinan, Shandong, P.R. China;

${ }^{3}$ Hepato-Biliary-Pancreatic Surgery Division, Department of Surgery, Graduate School of Medicine, the University of Tokyo, Tokyo; ${ }^{4}$ Department of Applied Biochemistry, Tokai University, Kanagawa, Japan
\end{abstract}

Received January 16, 2006; Accepted March 9, 2006

\begin{abstract}
Curcumin, one of the major components of tumeric, the dried rhizome of Curcuma longa $\mathrm{L}$, has been shown to have anti-proliferating and anti-carcinogenic properties. In this study, we examined the effects of curcumin on cell growth and telomerase activity in human cancer cell lines Bel7402, HL60 and SGC7901. Curcumin (1-32 $\mu \mathrm{M})$ showed antiproliferating effects on these cell lines in a dose-dependent manner in vitro, and anti-tumor effects when curcumin (50-200 $\mathrm{mg} / \mathrm{kg}$ ) was orally administered to nude mice transplanted with the cancer cells. When the cells were treated with $1 \mu \mathrm{M}$ of curcumin for $120 \mathrm{~h}$, apoptotic cells were observed by means of the adridine orange/ethidium bromide staining method, single cell microgel electrophoresis and flow cytometric analysis. On the other hand, suppression of telomerase activity in extracts of the cells treated with $1 \mu \mathrm{M}$ of curcumin was observed by means of a telomeric repeat amplification protocol - silver staining assay. These results suggest that curcumin could suppress telomerase activity in the cancer cell lines and that the decrease of telomerase expression followed by induction of apoptosis might be involved in the anti-proliferating effect of curcumin.
\end{abstract}

\section{Introduction}

Despite significant advances in medical technology for diagnosis and treatment, cancer is still widely posing a threat of mortality. Considerable attention has been focused on identifying naturally occurring chemopreventive substances capable of inhibiting, retarding or reversing the process of

Correspondence to: Dr Wei Tang, Hepato-Biliary-Pancreatic Surgery Division, Department of Surgery, Graduate School of Medicine, The University of Tokyo, 7-3-1 Hongo, Bunkyo-ku, Tokyo 113-8655, Japan

E-mail: tang-sur@h.u-tokyo.ac.jp

Key words: curcumin, telomerase, apoptosis, cancer multistage carcinogenesis. A wide spectrum of phenolic substances, particularly those present in dietary and medicinal plants, have been reported to possess substantial anticarcinogenic and anti-mutagenic effects $(1,2)$. The majority of these substances retain anti-oxidative and anti-inflammatory properties, which appear to contribute to their chemopreventive activity (3). Curcumin (diferulolylmethane) is one of the major components of turmeric, the dried rhizome of Curcuma longa $\mathrm{L}$, which has been used for centuries as a naturally occurring herbal remedy for treatment of inflammatory disorders as well as many other diseases (4). Curcumin has been shown to be an anti-oxidant that has antiproliferating and anti-carcinogenic properties (5). It has been reported that the induction of apoptosis by curcumin is responsible for such an anti-proliferating effect $(6,7)$, although the mechanism remains to be elucidated. On the other hand, it has been suggested that maintenance of telomere integrity protect cells from apoptosis and that inhibition of telomerase, an enzyme participating in telomeric DNA elongation, elicits an apoptotic response in cancer cells $(8,9)$.

In this study, in order to clarify the mechanism of the antiproliferating effect of curcumin, we confirmed cell growth inhibition and induction of apoptosis by curcumin and then examined the effect of curcumin on telomerase activity in various human cancer cell lines.

\section{Materials and methods}

Chemicals. Curcumin was purchased from Sigma-Aldrich (St. Louis, MO), and dissolved in dimethylsulfoxide (DMSO) for in vitro study or in 5\% amylum for in vivo study.

Cells. HL60 cells were provided by P. Yang of Experimental Hematology, Institute of Hematology, Tianjin, China. Bel7402 and SGC7901 cells were obtained from Shanghai Institute of Cell Biology, Chinese Academy of Sciences, Shanghai, China. Cells were grown in RPMI-1640 supplemented with 10\% heatinactivated fetal bovine serum, $2 \mathrm{mM}$ glutamine, penicillin and streptomycin in a humidified atmosphere $\left(5 \% \mathrm{CO}_{2}\right)$ at $37^{\circ} \mathrm{C}$. Cells were fed every 3-4 days, and Bel7402 and 

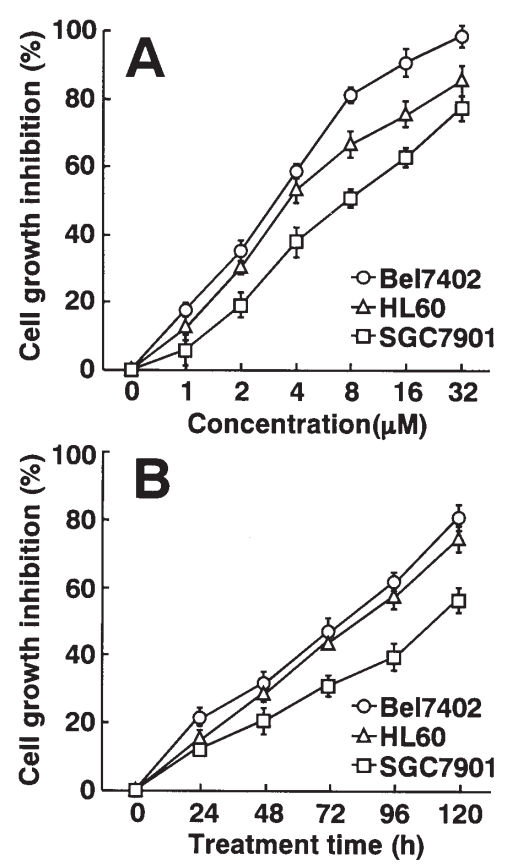

Figure 1. Cell growth inhibition by curcumin in vitro. Bel7402, HL60 and SGC7901 cells were treated with various concentrations of curcumin for $96 \mathrm{~h}$ (A) or with $4 \mu \mathrm{M}$ of curcumin for various incubation times (B). Viable cell numbers were evaluated by the MTT assay and are denoted as a percent of that of untreated controls at the concurrent time point. The bars indicate means $\pm \operatorname{SD}(n=3)$.

SGC7901 cells were harvested by brief incubation with $0.02 \%$ EDTA. Cell viability was assessed by the 3-[4,5-dimethylthiazol-2-yl]-2,5-diphenyl-tetrazolium bromide (MTT) assay (10).

Xenografts in nude mice. Female BALB/c athymic (nu+/nu+) mice, 4-6 weeks of age, were obtained from Experimental Animal Laboratory at the Chinese Academy of Medical Sciences (Beijing, China). The research protocol was approved in accordance with the institutional guidelines of the Shandong Academy of Medical Sciences Animal Care and Use Committee. Mice were injected s.c. with $1 \times 10^{7}$ cancer cells suspended in $200 \mu 1$ of matrigel (Collaborative Biomedical Products, Bedford, MA) into the dorsal flank. After 7 days, when tumor volume reached $\sim 0.2-0.3 \mathrm{~cm}^{3}$, the mice were orally administered $0-200 \mathrm{mg} / \mathrm{kg}$ of curcumin everyday for 5 consecutive weeks. Tumor size was measured every week as reported elsewhere (11).

Assessment of apoptosis induction. Induction of apoptosis by curcumin was assessed by means of an adridine orange/ ethidium bromide staining method, single cell microgel electrophoresis, and flow cytometric analysis. For adridine orange/ethidium bromide staining (12), $25 \mu 1$ of cell suspension $\left(10^{6}\right.$ cells $\left./ \mathrm{ml}\right)$ was incubated with $1 \mu 1$ of the adridine orange/ethidium bromide solution $(50 \mu \mathrm{g} / \mathrm{ml}$ each in PBS) followed by observation with a fluorescence microscope (magnification, $\mathrm{x} 400$ ). To analyze the level of DNA damage in individual cells for single cell microgel electrophoresis (13), the cells were embedded in $1 \%$ agarose and then put in a weak electric field followed by staining the
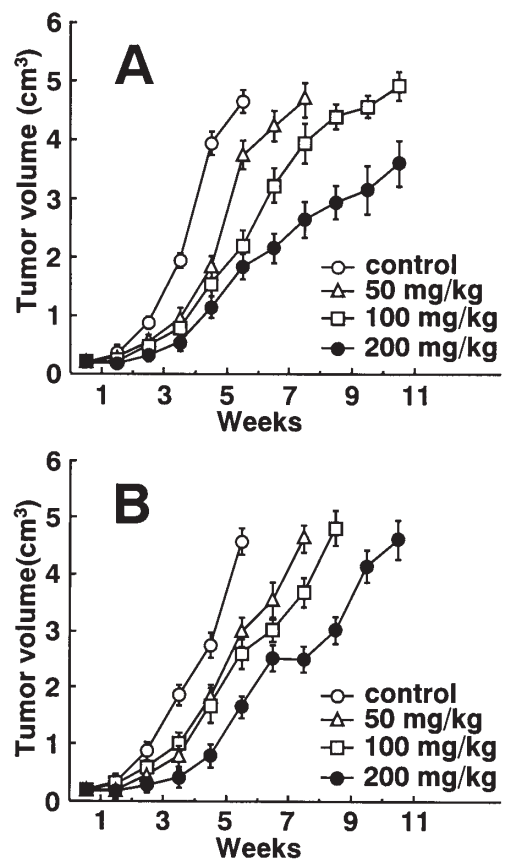

Figure 2. Anti-tumour activity of curcumin in vivo. Nude mice were injected s.c. in the dorsal flank with $1 \times 10^{7}$ cells of Bel7402 (A) or SGC7901 (B), and then the indicated doses of curcumin were orally administered, as described in Materials and methods. Tumor volume was measured every week during the life span. The bars indicate means \pm SD $(n=10)$.

DNA with acridine orange. For flow cytometric analysis (14), cells were subjected to PI staining and then analyzed by flow cytometry (FACS-Calibur; BD Biosciences, San Jose, CA) equipped with a $5 \mathrm{~W}$ argon ion laser tuned to $488 \mathrm{~nm}$ at 200 $\mathrm{mW}$ and CellQuest software.

Telomerase activity. Telomerase activity in cells was measured using a telomeric repeat amplification protocol (TRAP)-silver staining assay (15). In brief, curcumin-treated or untreated cells $\left(10^{6}\right.$ cells each) were lysed with a lysis buffer on ice for $30 \mathrm{~min}$ and then centrifuged at $12,000 \mathrm{rpm}$ for $20 \mathrm{~min}$ at $4^{\circ} \mathrm{C}$. The supernatant ( $1 \mu \mathrm{g}$ protein) was added to $48 \mu \mathrm{l}$ of the reaction mixture containing TRAP buffer, dNTP mix, TS primer, RP primer, Ki primer and 2 units of Taq polymerase. PCR conditions were cycles at $94^{\circ} \mathrm{C}$ for $30 \mathrm{sec}$, and $59^{\circ} \mathrm{C}$ for $30 \mathrm{sec}$. The PCR products were separated on $12.5 \%$ non-denaturing polyacrylamide gels and stained with silver. Quantification of the PCR products was performed as described elsewhere (16).

\section{Results}

Inhibitory effects of curcumin on cancer cell growth in vitro and in vivo. Effect of curcumin on cell growth was examined with Bel7402, HL60, and SGC7901 cells. As shown in Fig. 1, growth of these three cell lines was inhibited by curcumin in a dose- and time-dependent manner. When the cells were exposed to curcumin for $96 \mathrm{~h}, \mathrm{IC}_{50} \mathrm{~s}$ for HL60, Bel7402, and SGC7901 cell lines were $3.11,3.83$, and $8.00 \mu \mathrm{M}$, respectively.

Effects of curcumin on Bel7402 and SGC7901 xenografts in nude mice were then examined. As shown in Fig. 2, 

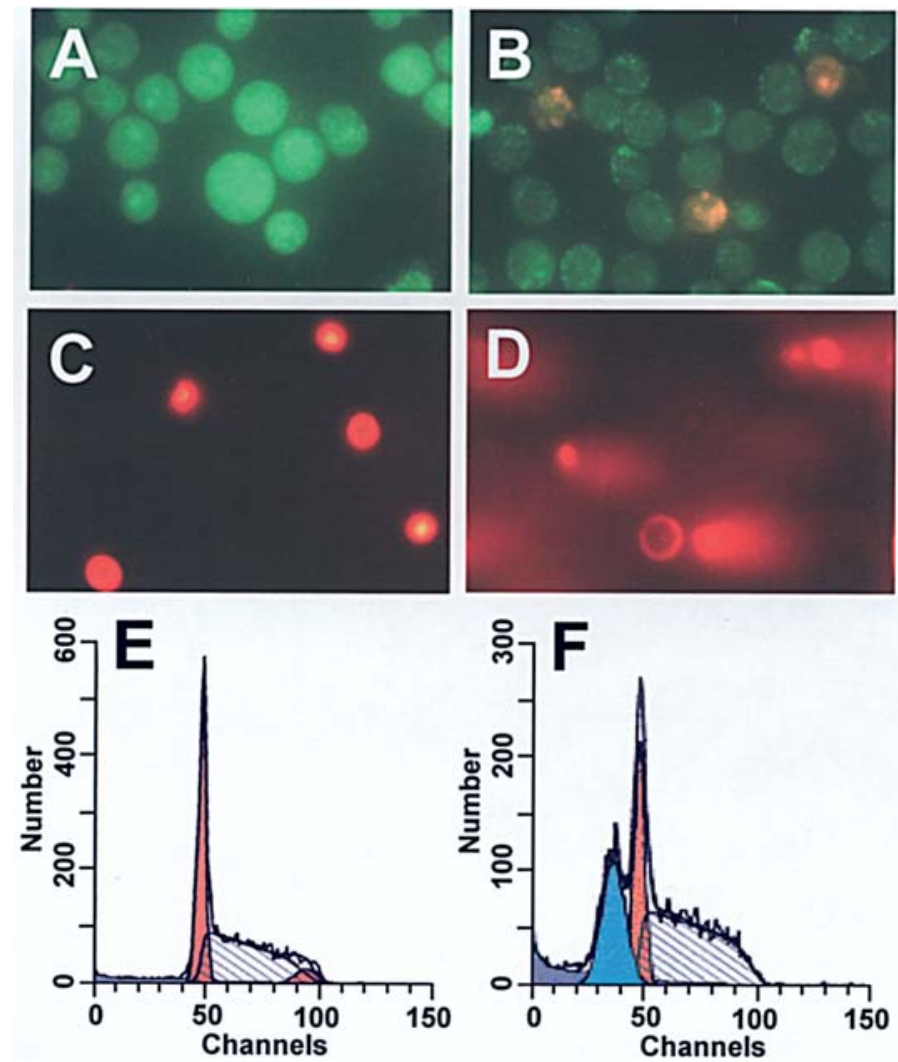

Figure 3. Induction of apoptosis by curcumin. HL60 cells were treated without (A, C and E) or with (B, D and F) $1.0 \mu \mathrm{M}$ of curcumin for $120 \mathrm{~h}$. The cells were then subjected to adridine orange/ethidium bromide staining of apoptotic cells (A and B; original magnification, $\mathrm{x} 400$ ), single cell electrophoresis analysis to examine nuclear DNA strand breakage (C and D), and flow cytometry after PI staining for detection of DNA fragmentation (E and F).

curcumin treatment produced a dose-dependent inhibition of tumor growth. This inhibitory effect on xenografts was more pronounced in Bel7402 cells than in SGC7901 cells. Delayed tumor growth was accompanied by a prolonged life span of mice which was significantly longer than that of untreated controls (data not shown). Curcumin treatment was generally well tolerated by mice with no signs of acute or delayed toxicity or reduction in body weight (data not shown). In the following in vitro experiments, we preferably chose a low concentration of curcumin $(1 \mu \mathrm{M})$, giving consideration to the future clinical application.

Induction of apoptosis by curcumin. We next examined whether curcumin can induce apoptosis using HL60 cells in vitro. Curcumin-untreated and -treated cells were subjected to an adridine orange/ethidium bromide staining method (Fig. 3A and B, respectively). Early apoptotic cells, which contained bright green dots in the nuclei as a consequence of chromatin condensation and nuclear fragmentation, and late apoptotic cells, which showed orange-colored condensation of nuclei, were observed after treatment with $1.0 \mu \mathrm{M}$ of curcumin for $120 \mathrm{~h}$ (Fig. 3B). Single cell electrophoresis analysis was also performed to examine nuclear DNA strand breakage (Fig. 3C and D). As shown in Fig. 3D, curcumin-treated cells migrated like a 'comet' with a brightly fluorescent head and a long tail region, suggesting an increment of broken DNA

\section{Treatment time (h)}
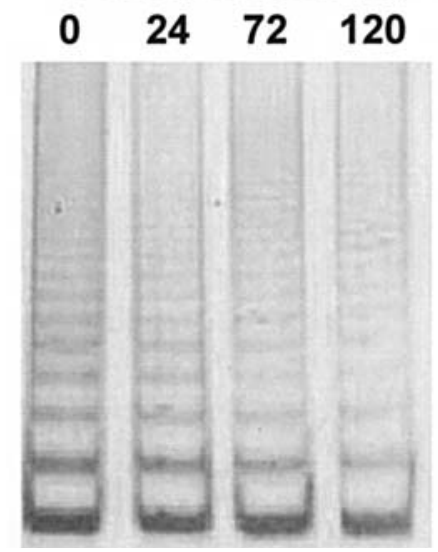

Figure 4. Typical separation profiles of PCR products on $12.5 \%$ nondenaturing polyacrylamide gel. Bel7407 cells were treated with $1 \mu \mathrm{M}$ of curcumin for the indicated incubation time. The cell extracts were subjected to a TRAP-silver staining assay.

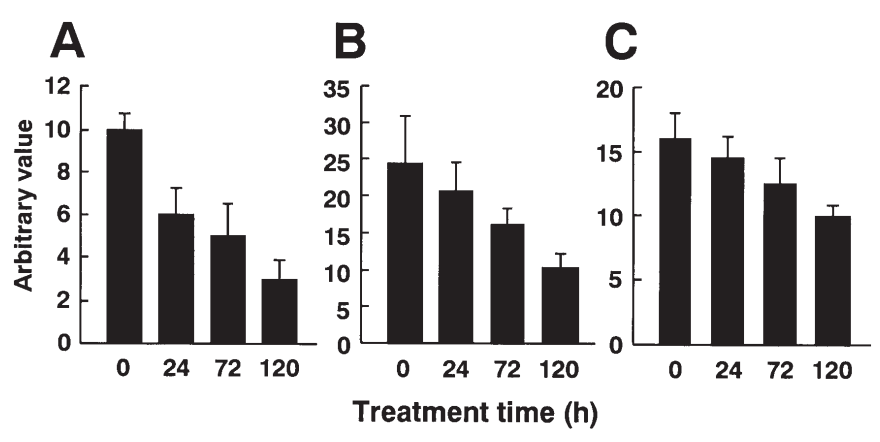

Figure 5. Suppression of telomerase activity in cancer cell lines by curcumin. Bel7402 (A), HL60 (B) and SGC7901 (C) cells were treated with $1 \mu \mathrm{M}$ of curcumin for the indicated incubation time. Telomerase activity in the cell extracts was measured by a TRAP-silver staining assay as described in Materials and methods. The bars indicate means $\pm \operatorname{SD}(n=3)$.

in the cells. Furthermore, apoptotic body formation was confirmed by means of flow cytometric analysis after PI staining of the cells treated without or with $1.0 \mu \mathrm{M}$ curcumin (Fig. 3E and F, respectively). As shown in Fig. 3F, a subdiploid peak (blue-colored) was observed in curcumin-treated HL60 cells, suggesting the appearance of apoptotic nuclei as a result of the partial loss of DNA due to leakage of lowmolecular-weight fragments generated during apoptosis. The area of the sub-diploid peak was enlarged in a treatment timedependent manner (data not shown). These results suggest that curcumin can induce apoptosis.

Inhibitory effect of curcumin on telomerase activity in cancer cell lines. Telomerase activity in cancer cell lines after exposure to curcumin for different incubation times was assessed by a TRAP-silver staining assay. Fig. 4 shows an example of typical analysis of the PCR products by telomerase in cell extracts. Quantification of the PCR products showed that telomerase activity in all three cell lines was decreased by the incubation with $1.0 \mu \mathrm{M}$ curcumin in a time-dependent manner (Fig. 5). At $120 \mathrm{~h}$-incubation time, the percent of inhibition of 
telomerase activity in Bel7402, HL60 and SGC7901 cell lines was $70.0,58.0$, and $37.4 \%$, respectively. Inhibitory efficiency was closely correlated with the sensitivity of antiproliferating effects of curcumin on each of the three cell lines. These results suggest that curcumin might inhibit cell growth through reducing telomerase activity followed by induction of apoptosis.

\section{Discussion}

A significant amount of research has showed that curcumin might affect several cellular processes involved in tumorigenesis and progression $(4,17)$. In the present study, we focused on the effect of curcumin on telomerase activity to clarify the anti-proliferating effect of curcumin. Curcumin exerted an anti-proliferating effect on human cancer cell lines in vitro and in vivo (Figs. 1 and 2). Furthermore, curcumin-treated cells proved that curcumin induces apoptosis and suppresses telomerase activity (Figs. 3 and 4). It has been suggested that tumor cell growth inhibition is associated with the promotion of apoptosis and decrease in telomerase expression $(8,9,18,19)$. Therefore, curcumin may inhibit cancer cell growth and induce apoptosis via reducing telomerase expression.

Telomerase is a ribonucleoprotein reverse transcriptase that is suppressed in normal somatic cells and is activated in cancer cells and immortalized cell lines (20). The catalytic core of human telomerase consists of an RNA template (hTR), a catalytic protein subunit with reverse transcriptase activity (hTERT) and additional telomerase-associated proteins such as hTEP1, p23, Hsp90, and dyskerin (21). hTERT acts as a limiting factor for telomerase activity. Expression of hTERT mRNA closely coincides with the presence of telomerase activity in cancer (22-25). Inhibition of hTERT expression results in loss of telomere and limits the growth of cancer cells. It has been proven that curcumin can down-regulate expression of several genes such as mutation-type of $p 53, b c l-2, c-m y c$ pro-oncogenes and protein kinase $C$ in cancer cells (26-28), which induce suppression of cell proliferation. Although the mechanism of modulation of telomerase expression by curcumin in cancer cells is still unknown, down-regulation of hTERT expression might be one of the physiological actions of curcumin, which promotes an apoptotic response in cancer cells.

Curcumin has been reported to inhibit reactive oxygengenerating enzymes such as lipooxygenase/cyclooxygenase, xanthine dehydroxygenase/oxidase, and nitric oxide synthase (29-33), as well as epidermal growth factor receptor intrinsic kinase activity (34), NF- $\mathrm{\kappa B}$ activity (35), and protein kinase C activity (26). In contrast, curcumin has been found to be fairly safe without toxic side effects (17), which is also suggested in the present study involving cancer xenografts in immunodeficient mice (data not shown). This study suggests the inhibitory effect of curcumin on telomerase activity. Further understanding of the physiological mechanisms of curcumin would establish the value of curcumin as a chemopreventive or therapeutic agent.

In summary, curcumin exerts an anti-proliferation effect on human cancer cell lines in vitro and in vivo. Biological effect of curcumin is multi-functional and the inhibition of telomerase expression followed by induction of apoptosis may be one of the major components that curcumin provides pertaining to anti-proliferation of cancer cells.

\section{Acknowledgements}

This work was supported by National Natural Science Foundation of China and Key Project of Cancer Drug Research, Department of Science and Technology, Shandong province, China). We thank the Department of Personnel of Shandong Province for providing the support to study in The University of Tokyo.

\section{References}

1. D'Incalci M, Steward WP and Gescher AJ: Use of cancer chemopreventive phytochemicals as antineoplastic agents. Lancet Oncol 6: 899-904, 2005.

2. Tsuda H, Ohshima Y, Nomoto H, Fujita K, Matsuda E, Iigo M, Takasuka N and Moore MA: Cancer prevention by natural compounds. Drug Metab Pharmacokinet 19: 245-263, 2004.

3. Kawanishi S, Oikawa S and Murata M: Evaluation for safety of antioxidant chemopreventive agents. Antioxid Redox Signal 7: 1728-1739, 2005.

4. Sharma RA, Gescher AJ and Steward WP: Curcumin: the story so far. Eur J Cancer 41: 1955-1968, 2005.

5. Duvoix A, Blasius R, Delhalle S, Schnekenburger M, Morceau F, Henry E, Dicato M and Diederich M: Chemopreventive and therapeutic effects of curcumin. Cancer Lett 223: 181-190, 2005 .

6. Ramachandran C and You W: Differential sensitivity of human mammary epithelial and breast carcinoma cell lines to curcumin. Breast Cancer Res Treat 54: 269-278, 1999.

7. Moos PJ, Edes K, Mullally JE and Fitzpatrick FA: Curcumin impairs tumor suppressor p53 function in colon cancer cells. Carcinogenesis 25: 1611-1617, 2004.

8. Mondello C and Scovassi AI: Telomeres, telomerase, and apoptosis. Biochem Cell Biol 82: 498-507, 2004.

9. Zhang Z, Liong EC, Lau TY, Leung KM, Fung PC and Tipoe GL: Induction of apoptosis by hexamethylene bisacetamide is p53dependent associated with telomerase activity but not with terminal differentiation. Int J Oncol 16: 887-892, 2000.

10. Carmichael J, DeGraff WG, Gazdar AF, Minna JD and Mitchell JB: Evaluation of a tetrazolium-based semiautomated colorimetric assay: assessment of chemosensitivity testing. Cancer Res 47: 936-942, 1987.

11. Ciardiello F, Caputo R, Bianco R, Damiano V, Pomatico G, De Placido S, Bianco AR and Tortora G: Antitumor effect and potentiation of cytotoxic drugs activity in human cancer cells by ZD-1839 (Iressa), an epidermal growth factor receptor-selective tyrosine kinase inhibitor. Clin Cancer Res 6: 2053-2063, 2000.

12. Cohen JJ: Apoptosis. Immunol Today 14: 126-130, 1993.

13. Ostling $\mathrm{O}$ and Johanson KJ: Microelectrophoretic study of radiation-induced DNA damages in individual mammalian cells. Biochem Biophys Res Commun 123: 291-298, 1984.

14. Nicoletti I, Migliorati G, Pagliacci MC, Grignani F and Riccardi C: A rapid and simple method for measuring thymocyte apoptosis by propidium iodide staining and flow cytometry. J Immunol Methods 139: 271-279, 1991.

15. Nemos C, Remy-Martin JP, Adami P, Arbez-Gindre F, Schaal JP, Jouvenot $M$ and Delage-Mourroux R: Improved TRAP-silver staining versus conventional radioactive TRAP assays: quantification of telomerase activity during immortalization and in pathological human endometrium. Clin Biochem 36: 621-628, 2003.

16. Wang $\mathrm{L}$ and Zhu X: Spatiotemporal relationships among D-serine, serine racemase, and D-amino acid oxidase during mouse postnatal development. Acta Pharmacol Sin 24: 965-974, 2003.

17. Aggarwal BB, Kumar A and Bharti AC: Anticancer potential of curcumin: preclinical and clinical studies. Anticancer Res 23: 363-398, 2003.

18. Aragona M, Maisano R, Panetta S, Giudice A, Morelli M, La Torre I and La Torre F: Telomere length maintenance in aging and carcinogenesis. Int J Oncol 17: 981-989, 2000.

19. Harrington L and Robinson MO: Telomere dysfunction: multiple paths to the same end. Oncogene 21: 592-597, 2002. 
20. Hsu YH and Lin JJ: Telomere and telomerase as targets for anti-cancer and regeneration therapies. Acta Pharmacol Sin 26: 513-518, 2005.

21. Smogorzewska A and de Lange T: Regulation of telomerase by telomeric proteins. Annu Rev Biochem 73: 177-208, 2004.

22. Boldrini L, Faviana P, Gisfredi S, Donati V, Zucconi Y, Ursino S, Simi P, Baldinotti F, Berti P, Galleri D, Materazzi G, Basolo F, Miccoli P, Pingitore R and Fontanini G: Regulation of telomerase and its hTERT messenger in colorectal cancer. Oncol Rep 11: 395-400, 2004.

23. Kanamaru T, Tanaka K, Kotani J, Ueno K, Yamamoto M, Idei Y, Hisatomi $\mathrm{H}$ and Takeyama Y: Telomerase activity and hTERT mRNA in development and progression of adenoma to colorectal cancer. Int J Mol Med 10: 205-210, 2002.

24. Hahn WC and Meyerson M: Telomerase activation, cellular immortalization and cancer. Ann Med 33: 123-129, 2001

25. Kiyozuka Y, Asai A, Senzaki H, Uemura Y, Nakashima A, Morimoto J, Matsuzawa A and Tsubura A: Telomere length, telomerase activity and telomerase RNA expression during mouse mammary tumor progression. Int J Mol Med 2: 437-444, 1998.

26. Lin JK: Suppression of protein kinase C and nuclear oncogene expression as possible action mechanisms of cancer chemoprevention by Curcumin. Arch Pharm Res 27: 683-692, 2004.

27. Pal S, Choudhuri T, Chattopadhyay S, Bhattacharya A, Datta GK, Das T and Sa G: Mechanisms of curcumin-induced apoptosis of Ehrlich's ascites carcinoma cells. Biochem Biophys Res Commun 288: 658-665, 2001.

28. Jiang MC, Yang-Yen HF, Lin JK and Yen JJ: Differential regulation of $\mathrm{p} 53, \mathrm{c}-\mathrm{Myc}, \mathrm{Bcl}-2$ and $\mathrm{Bax}$ protein expression during apoptosis induced by widely divergent stimuli in human hepatoblastoma cells. Oncogene 13: 609-616, 1996.
29. Skrzypczak-Jankun E, Zhou K, McCabe NP, Selman SH and Jankun J: Structure of curcumin in complex with lipoxygenase and its significance in cancer. Int J Mol Med 12: 17-24, 2003.

30. Balasubramanyam M, Koteswari AA, Kumar RS, Monicraraj SF, Mahesari SU, Mohan V: Curcumin-induced inhibition of cellular reactive oxygen species generation: novel therapeutic implications. J Biosci 28: 715-721, 2003.

31. Shao ZM, Shen ZZ, Liu CH, Sartippour MR, Go VL, Heber D and Nguyen M: Curcumin exerts multiple suppressive effects on human breast carcinoma cells. Int J Cancer 98: 234-240, 2002.

32. Ireson C, Orr S, Jone DJ, Verschoyle R, Lim CK, Luo JL, Howells L, Plummer S, Jukes R, Williams M, Steward WP and Gescher A: Characterization of metabolites of the chemopreventive agent curcumin in human and rat hepatocytes and in the rat in vivo, and evaluation of their ability to inhibit phorbol ester-induced prostaglandin E2 production. Cancer Res 61: 1058-1064, 2001.

33. Skrzypczak-Jankun E, McCabe NP, Selman SH and Jankun J: Curcumin inhibits lipoxygenase by binding to its central cavity: theoretical and X-ray evidence. Int J Mol Med 6: 521-526, 2000 .

34. Korutla L and Kumar R: Inhibitory effect of curcumin on epidermal growth factor receptor kinase activity in A431 cells. Biochim Biophys Acta 1224: 597-600, 1994.

35. Anto RJ, Venkatraman M and Karunagaran D: Inhibition of NF- $\kappa$ B sensitizes A431 cells to epidermal growth factor-induced apoptosis, whereas its activation by ectopic expression of RelA confers resistance. J Biol Chem 278: 25490-25498, 2003. 